\title{
Intake, digestibility, ruminal parameters, and microbial protein synthesis in crossbred steers fed diets based on Brachiaria grass silage and sorghum silage
}

\author{
[Consumo, digestibilidade, parâmetros ruminais e síntese de proteína microbiana em novilhos cruzados \\ alimentados com dietas a base de silagem de braquiária e silagem de sorgo]
F.H.M. Chizzotti ${ }^{1}$, O.G. Pereira ${ }^{2}$, S.C. Valadares Filho ${ }^{2}$, M.L. Chizzotti ${ }^{3}$, M.I. Leão ${ }^{2}$, D.H. Pereira ${ }^{2}$, L.O. Tedeschi ${ }^{4}$ \\ ${ }^{1}$ Universidade Federal do Vale do São Francisco - Petrolina, PE \\ ${ }^{2}$ Universidade Federal de Viçosa - Viçosa, MG \\ ${ }^{3}$ Universidade Federal de Lavras - Lavras, MG \\ ${ }^{4}$ Texas A \& M University, Department of Animal Science \\ College Station, Texas 77843, USA
}

\begin{abstract}
A trial was carried out with four Holstein $\mathrm{x}$ Nellore crossbred steers $(225 \pm 22 \mathrm{~kg}$ of BW) fitted with ruminal and abomasal cannulaes in a $4 \times 4$ Latin Square design to evaluate the intake and the total and partial apparent digestibilities of nutrients, ruminal parameters, and microbial synthesis. Diets consisted of $60 \%$ silage and $40 \%$ concentrate formulated to be isonitrogenous (12.5\% of crude protein, dry matter basis). Treatments consisted of different proportions of Brachiaria brizantha grass silage and sorghum silage: 100:0; 67:33; 33:67, and $0: 100 \%$, respectively, on dry matter basis. The intake of dry matter, organic matter, crude protein, ether extract, non-fiber carbohydrates, and total digestible nutrients linearly increased $(\mathrm{P}<0.01)$ as levels of sorghum silage increased. The total apparent digestibility of dry matter, organic matter, and neutral detergent fiber linearly increased with sorghum silage levels $(\mathrm{P}<0.02)$. The highest ruminal NH3-N $(13.63 \mathrm{mg} / \mathrm{dL})$ levels occurred at $2.94 \mathrm{~h}$ post-feeding whereas the lowest ruminal $\mathrm{pH}(5.87)$ was measured at $5.21 \mathrm{~h}$ post-feeding. Microbial efficiency was not affected $(\mathrm{P}>0.05)$ by the treatments. The use of $67 \%$ of sorghum silage and $33 \%$ of grass silage increased intake and digestibility of nutrients without affecting ruminal $\mathrm{pH}$, ruminal $\mathrm{NH} 3-\mathrm{N}$, and microbial efficiency.
\end{abstract}

Keywords: Brachiaria brizantha, microbial efficiency, total digestible nutrients

\section{RESUMO}

Realizou-se um estudo com quatro novilhos cruzados Holandês $x$ Nelore (225 $\pm 22 \mathrm{~kg}$ de peso vivo), canulados no rúmen e abomaso, distribuídos em quadrado latino $4 \times 4$ para avaliar o efeito de diferentes proporções de silagem de Braquiária brizantha e silagem de sorgo sobre o consumo e a digestibilidade dos nutrientes no trato digestório total e parcial, sobre os parâmetros ruminais e sobre a eficiência microbiana. As dietas continham $60 \%$ de volumoso e $40 \%$ de concentrado e foram formuladas para serem isonitrogenadas (12,5\% de proteina bruta na matéria seca). Os tratamentos consistiram em diferentes proporções de silagens de Brachiaria brizantha e de sorgo: 100:0; 67:33; 33:67 e 0:100\%, respectivamente (\% da matéria seca). O consumo de matéria seca, matéria orgânica, proteína bruta, extrato etéreo, carboidratos não-fibrosos e nutrientes digestiveis totais aumentou linearmente $(P<0,01)$ com o aumento da proporção de silagem de sorgo. A digestibilidade total da matéria seca, da matéria orgânica e da fibra em detergente neutro também aumentou linearmente $(P<0,02)$ com o aumento da proporção de silagem de sorgo. A máxima concentração de $N$ amoniacal ruminal $(13,63 \mathrm{mg} / \mathrm{dL})$ ocorreu 2,94 horas após a alimentação enquanto o menor pH foi observado às 5,21 horas após a alimentação. A eficiência microbina não foi afetada pelos tratamentos (P>0,05). $O$ uso de $67 \%$ de silagem de sorgo com 33\% de silagem de braquiária aumentou o consumo e a digestibilidade dos nutrientes sem afetar o pH e $\mathrm{N}$-amoniacal ruminais, bem como a eficiência microbiana.

Palavras-chave: Brachiaria brizantha, eficiência microbiana, nutrientes digestiveis totais

Recebido em 14 de janeiro de 2009

Aceito em 30 de outubro de 2009

E-mail: fernandachizzotti@yahoo.com.br 


\section{INTRODUCTION}

Silage is an important form of conserved forage to feed ruminants during the winter in many regions around the world. However, it is difficult to ensure good quality silage using tropical grass because they usually have low water soluble carbohydrate content, and high buffering capacity, yielding low lactic acid production, and, consequently, a silage of poor quality (Catchpoole and Henzell, 1971). In fact, many studies have found that silage made from tropical grass generally have high $\mathrm{pH}$ and high acetic or butyric acid content (Imura et al., 2001), what negatively affect the dry matter (DM) intake and consequently, animal performance. On the other hand, using sorghum is easy to get good quality silage. Although sorghum has lesser nutritional value than maize, sorghum silage is an excellent source of forage for beef cattle, and, it has the advantage of regrowth, high drought and hot tolerance and, do not compete with human feeding (Zago, 1999).

Under tropical conditions, few studies have evaluated the effects of the association among different sources of forages in the diet on intake and digestibility of nutrients, animal performance, and ruminal fermentation kinetics in beef cattle. The combination of different forage sources can be a viable alternative to improve the performance of animals. Adoption this feeding strategy offers the potential to increase productivity due to the associative effects of mixed-forage diets on nutrient supply to cattle (Phipps et al., 1995; Wilkinson et al., 1998). Previous studies with beef (Souza et al., 2006) and dairy cattle (Ferreira et al., 1995; Phipps et al., 1995; O'Mara et al., 1998) have shown increased intake of forage when corn silage or sorghum silage has been incorporated into diets based on grass silage as the sole forage. However, grass silage of Brachiaria brizantha, a common grass in the tropical regions, has not been evaluated. Therefore, the objective with this study was to evaluate the effect of diets based on different proportions of Brachiaria brizantha grass silage and sorghum silage on intake, digestibility, ruminal parameters, and microbial protein efficiency in Holstein x Nellore crossbred steers.

\section{MATERIAL AND METHODS}

The study was carried out from July to September 2002. Four Holstein crossbred steers, averaging $225 \pm 22 \mathrm{~kg}$ of body weight (BW), were used in a $4 \times 4$ Latin square design to evaluate the intake and the total tract and partial apparent digestibilities of nutrients, ruminal passage rate, ruminal $\mathrm{pH}$, ruminal $\mathrm{NH} 3-\mathrm{N}$ concentration, and microbial protein synthesis. Steers were surgically fitted with ruminal and abomasal cannulaes in agreement with techniques described by Leão and Coelho da Silva (1980). Ruminal and abomasal cannulaes and surrounding areas were routinely cleaned during the trial.

Diets consisted of $60 \%$ silage and $40 \%$ concentrate, formulated to be isonitrogenous (12.5\% of crude protein (CP) on dry matter (DM) basis). Treatments consisted of different proportions of Brachiaria brizantha grass silage and sorghum silage: 100:0; 67:33; 33:67; and $0: 100 \%$ on DM basis.

Steers were individually fed ad libitum twice at 7AM and 3PM. Each experimental period was $17 \mathrm{~d}$ long and included 10d of adaptation to the diet, 6d for fecal and abomasal collection sampling and $1 \mathrm{~d}$ for ruminal $\mathrm{pH}$ measurement and collection of ruminal fluid samples. The experiment was carried out for $68 \mathrm{~d}$ (four periods of $17 d$ ).

For each animal, the intake was daily measured. Orts were collected and weighted once daily and the rate was adjusted to yield orts of about 5 to $10 \%$ of offered. Animals had access to water at all times. Feed ingredients and orts were daily sampled and composed by weight by period. Following the methodology described by Bolsen et al. (1992), $\mathrm{pH}$ and $\mathrm{NH}_{3}-\mathrm{N}$ measurements were taken from silage samples collected every $3 \mathrm{~d}$ during the whole experimental period.

Chromium oxide was used as an external marker to estimate apparent nutrient digestibility and fecal output. The external marker was added once daily at the dose of $15 \mathrm{~g}$, into the rumen, at $11 \mathrm{AM}$, from $\mathrm{d} 3$ to $\mathrm{d} 16$ of each experimental period. Feces and abomasal digesta were 
collected every $26 \mathrm{~h}$, starting at $8 \mathrm{AM}$ on d11 to $6 \mathrm{PM}$ on $\mathrm{d} 16$ of each experimental period. Abomasal digesta and fecal samples were dried in a forced draft oven $\left(60^{\circ} \mathrm{C}\right.$ for $\left.72 \mathrm{~h}\right)$, and then ground to pass a 1-mm screen. Composite samples of feces and abomasal digesta were made per animal (on dry weight basis) in each period. After drying at $60^{\circ} \mathrm{C}$ for $72 \mathrm{~h}$, feeds and orts also were ground to pass a 1-mm screen and period composites were prepared. Whole ruminal contents $(100 \mathrm{~mL})$ were obtained at $0,1,2,4,6$, and $8 \mathrm{~h}$ after the morning feeding on day 17 of each period. The ruminal content was strained through two layers of cheesecloth, and $\mathrm{pH}$ was immediately measured. The strained ruminal fluid was preserved by addition of $1 \mathrm{~mL}$ of $9 \mathrm{M}$ $\mathrm{H}_{2} \mathrm{SO}_{4}$, and stored at $-20^{\circ} \mathrm{C}$ for analysis of $\mathrm{NH}_{3}-$ $\mathrm{N}$ concentration.

The composite samples for each material (silage, concentrate, orts, abomasal digesta, and feces) were used to determine: dry matter (DM); organic matter (OM); crude protein $(\mathrm{CP})$, obtained by total $\mathrm{N}$ determination using the micro Kjeldahl technique and a fixed conversion factor (6.25); ether extract (EE), gravimetrically determined after extraction using petroleum ether in a Soxhlet instrument; acid detergent fiber (ADF) according to AOAC (Official..., 1990); neutral detergent fiber (NDF) according to Van Soest et al. (1991); and sulfuric acid lignin (lignin sa) according to Robertson and Van Soest (1981). Non-fiber carbohydrates (NFC) were calculated as $100-(\% \mathrm{CP}+\% \mathrm{NDF}+\% \mathrm{EE}+\%$ ash). NFC of the concentrate mix were calculated as $100-[(\% \mathrm{CP}-\% \mathrm{CP}$ from urea $+\%$ of urea $)+$ $\% \mathrm{NDF}+\%$ EE + \% ash $]$ (Hall, 2000); and apparent total digestible nutrients (TDN) calculated as: $(\mathrm{CP}$ intake - fecal $\mathrm{CP})+(\mathrm{NDF}$ intake - fecal NDF) + (NFC intake - fecal NFC) $+2.25 \times($ EE intake - fecal EE) (Sniffen et al., 1992). Passage rates were estimated according to NRC (Nutrient..., 2001) equations: $K p=3.054+$ $0.614 \mathrm{X} 1$ and $\mathrm{Kp}=2.904+1.375 \mathrm{X} 1-0.020 \mathrm{X} 2$ to wet forages and concentrate feed, respectively, in which $\mathrm{X} 1=\mathrm{DM}$ intake, as $\% \mathrm{BW}$, and $\mathrm{X} 2=\%$ of concentrate mix of the diet.

Chromium concentration in fecal and abomasal digesta was determined using atomic absorption with an air-acetylene flame (Williams et al., 1962). The determination of the contents of $\mathrm{NH}_{3}-$ $\mathrm{N}$ in samples of ruminal liquid was accomplished by a micro-Kjeldahl system without acid digestion and after distillation with potassium hydroxide $(2 \mathrm{~N})$, after previous centrifugation of the sample to $1.000 \mathrm{x} \mathrm{g}$ for 15 minutes.

To quantify microbial protein, approximately $400 \mathrm{mg}$ of dry samples of abomasal digesta were used. Purine derivatives were used as microbial markers for quantifying the flow of microbial protein at the abomasal canal, and were analyzed according to Ushida et al. (1985). The mean value $14.51 \%$ (Rennó, 2003), was used for the ratio N-RNA:Total - $\mathrm{N}$ of rumen bacteria.

Data of intake, digestibility, and microbial protein production were analyzed with the GLM procedure of SAS/1990 assuming a 4 x 4 Latin square design. Linear, quadratic, and cubic effects of dietary sorghum levels were tested using orthogonal contrasts. Differences were considered to be significant when $\mathrm{P}<0.05$.

The ruminal parameter data collected over time were analyzed as repeated measure design (Kuehl, 2000) using the GLM procedure of SAS. Model effects in the whole plot were animal, period, and treatment, whereas subplot effects were sampling time and treatment $\times$ sampling time interactions. Whole-plot model effects were tested using animal $\times$ period $\times$ treatment as the whole-plot error, whereas subplot model effects were tested using the residual error. When treatment by sampling time interaction was significant, variables were analyzed within time periods.

\section{RESULTS}

Chemical composition of silages is presented in Table 1 . The grass silage had $\mathrm{pH}$ value of 5.02 and $\mathrm{NH}_{3}-\mathrm{N} /$ Total $\mathrm{N}$ of $21.2 \%$. Additionally, a dark color and characteristic smell of badlyfermented silage were noted. In contrast, sorghum silage had $\mathrm{pH}$ of 4.24 and $\mathrm{NH}_{3}-\mathrm{N} /$ Total $\mathrm{N}$ of $6.42 \%$.

The nutrient composition of the diets is presented in Table 2. Diets provided different amounts of DM, OM, EE, NDF, indigestible acid detergent fiber (iADF), NFC, and TDN. The addition of sorghum silage increased dietary contents of TDN, EE, NCF, DM, and OM and decreased $\mathrm{NDF}$, iADF, lignin, neutral detergent insoluble nitrogen (NDIN), and acid detergent insoluble nitrogen (ADIN). 
Intake, digestibility, ruminal parameters...

Table 1. Chemical composition of grass and sorghum silages used to fed crossbred steers

\begin{tabular}{|c|c|c|}
\hline Item & Brachiaria grass & Sorghur \\
\hline DM, \% & 22.0 & 34.3 \\
\hline OM, \% DM & 92.5 & 95.2 \\
\hline $\mathrm{CP}, \% \mathrm{DM}$ & 9.0 & 6.32 \\
\hline NDIN, $\%$ total $\mathrm{N}$ & 50.2 & 35.5 \\
\hline ADIN, $\%$ total $N$ & 36.9 & 18.3 \\
\hline $\mathrm{EE}, \% \mathrm{DM}$ & 1.3 & 2.24 \\
\hline $\mathrm{NDF}, \% \mathrm{DM}$ & 74.2 & 60.5 \\
\hline $\mathrm{NFC}, \% \mathrm{DM}$ & 8.0 & 26.1 \\
\hline $\mathrm{ADF}, \% \mathrm{DM}$ & 50.0 & 36.9 \\
\hline Lignin, \%DM & 10.1 & 5.13 \\
\hline iADF, $\%$ DM & 35.3 & 20.3 \\
\hline $\mathrm{NH}_{3}-\mathrm{N}, \%$ of total $\mathrm{N}$ & 21.2 & 6.42 \\
\hline $\mathrm{pH}$ & 5.02 & 4.24 \\
\hline
\end{tabular}

$\mathrm{DM}=$ dry matter; $\mathrm{OM}=$ organic matter; $\mathrm{CP}=$ crude protein; $\mathrm{NDIN}=$ neutral detergent insoluble nitrogen; $\mathrm{ADIN}=\mathrm{acid}$ detergent insoluble nitrogen; $\mathrm{EE}=$ ether extract; $\mathrm{NDF}=$ neutral detergent fiber; $\mathrm{NFC}=$ non-fiber carbohydrates; $\mathrm{ADF}=$ acid detergent fiber; $\mathrm{iADF}=$ indigestible $\mathrm{ADF}$.

Table 2. Ingredients and chemical composition of diets used to fed crossbred steers according to the levels of sorghum silage

\begin{tabular}{lcccc} 
& \multicolumn{4}{c}{ Levels of sorghum silage, \% DM } \\
\cline { 2 - 4 } Item & 0 & 33 & 67 & 100 \\
\hline Grass silage & 60 & 40.2 & 19.8 & 0 \\
Sorghum silage & 0 & 19.8 & 40.2 & 60 \\
Ground corn & 33.9 & 31.7 & 29.4 & 27.2 \\
Soybean grain & 4.53 & 6.73 & 9.03 & 11.23 \\
Urea & 1.00 & 1.00 & 1.00 & 1.00 \\
Ammonium sulphate & 0.10 & 0.10 & 0.10 & 0.10 \\
Sodium chloride & 0.25 & 0.25 & 0.25 & 0.25 \\
Dicalcium phosphate & 0.20 & 0.20 & 0.20 \\
Mineral premix & 0.02 & 0.02 & 0.02 & 0.02 \\
\hline Nutrient content of diets, \% DM & & & 56.5 \\
\hline DM & 49.2 & 51.5 & 95.2 \\
OM & 93.8 & 94.5 & 95.1 & 128 \\
CP & 12.8 & 12.8 & 127 & 2.73 \\
NDIN & 3.46 & 3.26 & 3.02 & 1.36 \\
ADIN & 2.48 & 2.12 & 1.77 & 4.41 \\
EE & 2.89 & 3.32 & 3.87 & 40.9 \\
NDF & 48.9 & 46.2 & 43.5 & 12.8 \\
iADF & 21.7 & 18.8 & 15.7 & 37.1 \\
NFC & 29.1 & 32.1 & 34.8 & 3.84 \\
Lignin & 6.69 & 5.68 & 4.72 & 72.7 \\
TDN & 58.3 & 62.6 & 68.2 & \\
\hline
\end{tabular}

${ }^{1}$ Composition (g/kg): cupre sulphate (225), cobalt sulphate (14.0), zinc sulphate (754.0), potassium iodate (5.0), and sodium selenite (2.0).

$\mathrm{DM}=$ dry matter; $\mathrm{OM}=$ organic matter; $\mathrm{CP}=$ crude protein; $\mathrm{NDIN}=$ neutral detergent insoluble nitrogen; $\mathrm{ADIN}=$ acid detergent insoluble nitrogen; $\mathrm{EE}=$ ether extract; $\mathrm{NDF}=$ neutral detergent fiber; $\mathrm{iADF}=$ indigestible $\mathrm{ADF}$; $\mathrm{NFC}=$ non-fiber carbohydrates; $\mathrm{TDN}=$ total digestible nutrients.

${ }^{2}$ Observed. 
The effect of increasing sorghum silage in the diet augment the intake of nutrients (Table 3). Overall, only the NDF intake, $\mathrm{kg} / \mathrm{d}$, was not affected by the levels of sorghum silage, even though a tendency of linear effect was observed $(\mathrm{P}=0.06)$. The intake of DM, OM, CP, EE, NFC, and TDN had a positive linear relationship $(\mathrm{P}<0.01)$ as sorghum silage levels increased in the diets.

Total tract apparent digestibility of DM, OM, and NDF linearly increased $(\mathrm{P}<0.05)$ with addition of sorghum silage in the diets (Table 4).
On the other hand, sorghum silage had no effect $(\mathrm{P}>0.05)$ on the total apparent digestibility of $\mathrm{CP}$, $\mathrm{EE}$ and NFC.

There was an effect $(\mathrm{P}<0.05)$ of the levels of sorghum silage on apparent ruminal digestibility of DM, OM, and EE (Table 5). In contrast, ruminal digestibility of $\mathrm{CP}, \mathrm{NDF}$, and $\mathrm{NFC}$ were not affected $(\mathrm{P}>0.05)$. Additionally, apparent intestinal digestibility of DM and OM linearly decreased $(\mathrm{P}<0.05)$ as sorghum silage increased, while $\mathrm{CP}$, EE, NDF, and NFC intestinal digestibility were not affected $(\mathrm{P}>0.05)$.

Table 3. Intake of nutrients by crossbred steers according to the levels of sorghum silage

\begin{tabular}{|c|c|c|c|c|c|c|c|c|}
\hline & & um sil & vels, & & & & P-value ${ }^{1}$ & \\
\hline & 0 & 33 & 67 & 100 & SEM & Linear & Quadratic & Cubic \\
\hline Intake & & & & & & & & \\
\hline $\mathrm{DM}$ & 3.99 & 5.22 & 6.43 & 6.04 & 0.36 & $<0.01$ & 0.07 & 0.36 \\
\hline $\mathrm{OM}$ & 3.75 & 4.94 & 6.11 & 5.79 & 0.34 & $<0.01$ & 0.07 & 0.37 \\
\hline $\mathrm{CP}$ & 0.60 & 0.75 & 0.90 & 0.86 & 0.05 & $<0.01$ & 0.08 & 0.34 \\
\hline $\mathrm{EE}$ & 0.12 & 0.19 & 0.27 & 0.29 & 0.01 & $<0.01$ & 0.13 & 0.18 \\
\hline NDF & 1.78 & 2.28 & 2.63 & 2.33 & 0.19 & 0.06 & 0.07 & 0.57 \\
\hline NFC & 1.33 & 1.80 & 2.41 & 2.40 & 0.10 & $<0.01$ & 0.06 & 0.15 \\
\hline TDN & 2.49 & 3.51 & 4.55 & 4.46 & 0.23 & $<0.01$ & 0.06 & 0.30 \\
\hline Intake & & & & & & & & \\
\hline DM & 1.59 & 2.04 & 2.58 & 2.38 & 0.07 & $<0.01$ & $<0.01$ & 0.06 \\
\hline NDF & 0.71 & 0.89 & 1.05 & 0.92 & 0.04 & $<0.01$ & 0.01 & 0.19 \\
\hline
\end{tabular}

${ }^{\top}$ Probability of a significant linear, quadratic, or cubic effect of the levels sorghum silage in the diet.

$\mathrm{DM}=$ dry matter; $\mathrm{OM}=$ organic matter; $\mathrm{CP}=$ crude protein; $\mathrm{EE}=$ ether extract; $\mathrm{NDF}=$ neutral detergent fiber; $\mathrm{NFC}$

$=$ non-fiber carbohydrates, TDN $=$ total digestible nutrients; $\mathrm{BW}=$ body weight.

Table 4. Total tract apparent digestibility of nutrients of crossbred steers according to the levels of sorghum silage

\begin{tabular}{lccccccccc} 
& \multicolumn{3}{c}{ Levels of sorghum silage, $\%$ DM } & & \multicolumn{3}{c}{ P-value $^{1}$} \\
\cline { 2 - 4 } Digestibility & 0 & 33 & 67 & 100 & SEM & Linear & Quadratic & Cubic \\
\hline DM & 58.5 & 64.0 & 66.5 & 68.7 & 11.3 & $<0.01$ & 0.20 & 0.61 \\
OM & 59.5 & 64.5 & 67.7 & 70.0 & 10.4 & $<0.01$ & 0.24 & 0.88 \\
CP & 64.6 & 65.5 & 66.2 & 70.4 & 20.5 & 0.08 & 0.46 & 0.69 \\
EE & 80.0 & 78.5 & 77.2 & 80.6 & 34.9 & 0.92 & 0.54 & 0.74 \\
NDF & 40.9 & 47.8 & 51.7 & 50.7 & 22.0 & 0.02 & 0.12 & 0.88 \\
NFC & 85.6 & 87.4 & 87.9 & 89.3 & 11.9 & 0.21 & 0.80 & 0.87 \\
\hline
\end{tabular}

${ }^{\mathrm{T}}$ Probability of a significant linear, quadratic or cubic effect of the levels of sorghum silage in the diet. $\mathrm{DM}=$ dry matter; $\mathrm{OM}=$ organic matter; $\mathrm{CP}=$ crude protein; $\mathrm{EE}=$ ether extract; $\mathrm{NDF}=$ neutral detergent fiber; $\mathrm{NFC}=$ non-fiber carbohydrates. 
Intake, digestibility, ruminal parameters...

Table 5. Ruminal and intestinal digestibility of nutrients of crossbred steers according to the levels of sorghum silage

\begin{tabular}{|c|c|c|c|c|c|c|c|c|}
\hline \multirow[b]{2}{*}{ Item } & \multicolumn{4}{|c|}{ Levels of sorghum silage, $\%$ DM } & \multicolumn{4}{|c|}{ P-value ${ }^{3}$} \\
\hline & 0 & 33 & 67 & 100 & SEM & Linear & Quadratic & Cubic \\
\hline \multicolumn{9}{|c|}{ Ruminal digestibility, $\%$} \\
\hline $\mathrm{DM}^{1}$ & 57.5 & 62.5 & 69.5 & 69.0 & 15.0 & $<0.01$ & 0.12 & 0.21 \\
\hline $\mathrm{OM}^{1}$ & 61.1 & 67.4 & 72.7 & 74.1 & 17.8 & $<0.01$ & 0.23 & 0.83 \\
\hline $\mathrm{CP}^{2}$ & 38.5 & 38.7 & 38.0 & 41.7 & 39.3 & 0.63 & 0.67 & 0.76 \\
\hline $\mathrm{EE}^{2}$ & -30.0 & -15.2 & -9.75 & -3.75 & 65.9 & 0.03 & 0.53 & 0.75 \\
\hline $\mathrm{NDF}^{1}$ & 82.8 & 89.7 & 87.7 & 84.5 & 37.6 & 0.85 & 0.22 & 0.66 \\
\hline $\mathrm{NFC}^{1}$ & 71.7 & 67.5 & 80.3 & 78.5 & 48.4 & 0.17 & 0.81 & 0.19 \\
\hline \multicolumn{9}{|c|}{ Intestinal digestibility, $\%$} \\
\hline $\mathrm{DM}^{1}$ & 42.5 & 37.5 & 30.5 & 31.0 & 15.1 & $<.001$ & 0.11 & 0.21 \\
\hline $\mathrm{OM}^{1}$ & 38.9 & 32.6 & 27.3 & 25.9 & 17.8 & $<0.01$ & 0.23 & 0.83 \\
\hline $\mathrm{CP}^{2}$ & 42.2 & 43.0 & 45.0 & 48.7 & 44.9 & 0.32 & 0.75 & 0.98 \\
\hline $\mathrm{EE}^{2}$ & 84.0 & 80.7 & 79.5 & 81.0 & 39.5 & 0.58 & 0.56 & 0.96 \\
\hline $\mathrm{NDF}^{1}$ & 17.2 & 10.3 & 12.3 & 15.5 & 37.6 & 0.85 & 0.22 & 0.66 \\
\hline $\mathrm{NFC}^{1}$ & 28.3 & 32.5 & 19.7 & 21.5 & 48.4 & 0.17 & 0.81 & 0.19 \\
\hline
\end{tabular}

${ }^{1}$ Digestibility calculated as \% of total digestion.

${ }^{2}$ Digestibility calculated as \% of the amount that reached each compartment.

${ }^{3}$ Probability of a significant linear, quadratic, or cubic effect of the levels of sorghum silage in diet.

$\mathrm{DM}=$ dry matter; $\mathrm{OM}=$ organic matter; $\mathrm{CP}=$ crude protein; $\mathrm{EE}=$ ether extract; $\mathrm{NDF}=$ neutral detergent fiber; $\mathrm{NFC}=$ non-fiber carbohydrates.

Ruminal $\mathrm{pH}$ values were not affected either by the levels of sorghum silage $(\mathrm{P}=0.51)$ or by interaction between time and level of sorghum silage $(\mathrm{P}=0.98)$, but sampling time affected $(\mathrm{P}<0.0001)$ ruminal $\mathrm{pH}$ (Fig. 1). There was an effect of sampling time $(\mathrm{P}<0.0001)$ on ruminal NH3-N concentration (Fig. 2). However, the interaction between sampling time and level of sorghum silage in the diet was not affected $(\mathrm{P}=0.38)$. The average passage rates were 4.13 , $4.54,5.04$, and $4.85 \% / \mathrm{h}$ for diets with $0,33,67$, and $100 \%$ of sorghum silage, respectively. A quadratic behavior $(\mathrm{P}<0.05)$ with maximum passage rate of $4.95 \% / \mathrm{h}$ at $79.6 \%$ of sorghum silage in the diet was observed.

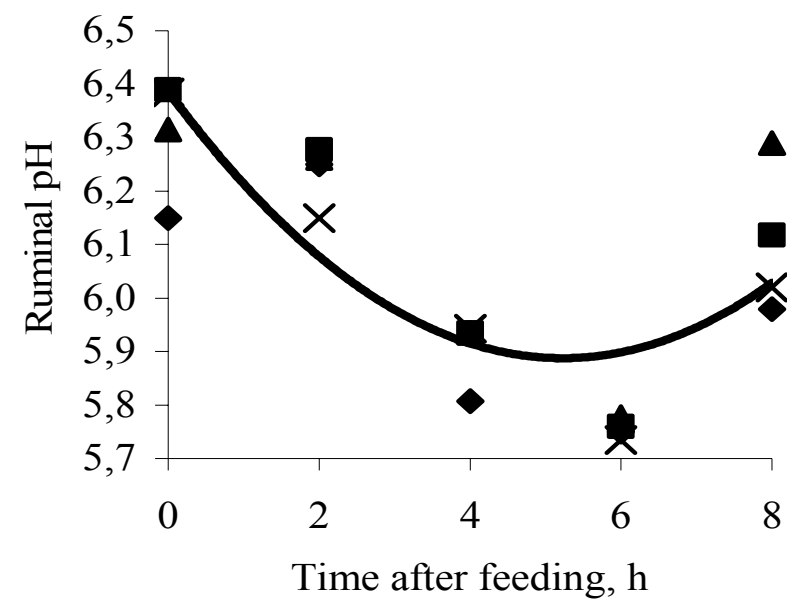

Figure 1. Ruminal $\mathrm{pH}$ after feeding crossbred steers.

$(\downarrow 100 \%$ grass silage; $67 \%$ grass silage and $33 \%$ of sorghum silage; $\boldsymbol{\Delta} 33 \%$ of grass silage and $67 \%$ sorghum silage; and $\mathrm{X} 100 \%$ sorghum silage) $\mathrm{pH}=0.0183 \mathrm{x}^{2}-0.1909 \mathrm{x}+6.3868 ; \mathrm{R}^{2}=0.64$. 


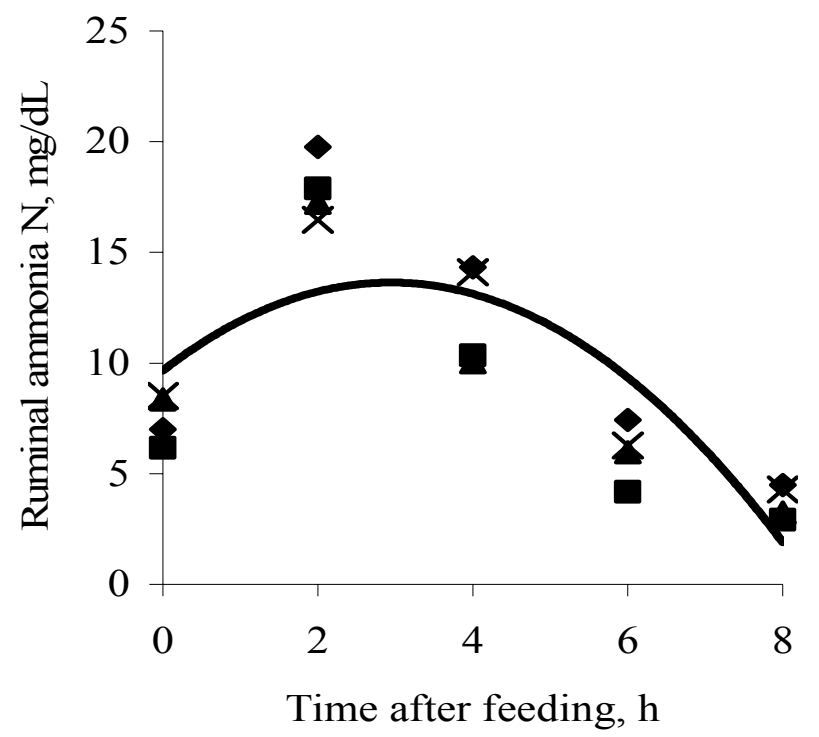

Figure 2. Ruminal NH3- N concentration after feeding crossbred steers.

( $\downarrow 100 \%$ grass silage; $67 \%$ grass silage and $33 \%$ of sorghum silage; $\boldsymbol{\Delta} 33 \%$ of grass silage and $67 \%$ sorghum silage; and $\mathrm{X} 100 \%$ sorghum silage). $\mathrm{NH}_{3}-\mathrm{N}=-0.4592 \mathrm{x}^{2}+2.7021 \mathrm{x}+9.6608 ; \mathrm{R}^{2}=0.63$.

There was a positive linear relationship between the levels of sorghum silage and microbial nitrogen production $(\mathrm{P}<0.02)$, rumen-degraded organic matter $(\mathrm{RDOM})(P<0.01)$, and rumendegraded carbohydrate (RDCHO) $(\mathrm{P}<0.01)$.
However, the efficiency of microbial production, $\mathrm{g}$ of microbial N/kg RDOM, g of microbial N/kg $\mathrm{RDCHO}$, and $\mathrm{g}$ of microbial crude protein $/ \mathrm{kg}$ TDN were not affected $(\mathrm{P}>0.05)$ by the levels of sorghum silage (Table 6).

Table 6. Microbial protein efficiency of crossbred steers according to the levels of sorghum silage

\begin{tabular}{|c|c|c|c|c|c|c|c|c|}
\hline \multirow[b]{2}{*}{ Item } & \multicolumn{4}{|c|}{ Levels of sorghum silage, $\%$ DM } & \multirow[b]{2}{*}{ SEM } & \multicolumn{3}{|c|}{ P-value ${ }^{3}$} \\
\hline & 0 & 33 & 67 & 100 & & Linear & Quadratic & Cubic \\
\hline $\operatorname{mic} N^{1}, g / d$ & 47.6 & 64.4 & 80.9 & 80.6 & 7.74 & $<0.02$ & 0.31 & 0.65 \\
\hline $\mathrm{RDOM}^{1}, \mathrm{~kg} / \mathrm{d}$ & 1.39 & 2.20 & 3.03 & 3.02 & 0.20 & $<0.01$ & 0.09 & 0.37 \\
\hline $\mathrm{RDCHO}^{1}, \mathrm{~kg} / \mathrm{d}$ & 1.40 & 2.05 & 2.85 & 2.64 & 0.20 & $<0.01$ & 0.07 & 0.25 \\
\hline $\mathrm{mic} \mathrm{N} / \mathrm{RDOM}^{2}$ & 35.3 & 31.3 & 27.4 & 27.3 & 2.32 & 0.36 & 0.42 & 0.72 \\
\hline $\begin{array}{l}\operatorname{mic} \mathrm{N} \\
/ \mathrm{RDCHO}^{2}\end{array}$ & 34.8 & 33.9 & 28.9 & 31.1 & 2.82 & 0.25 & 0.61 & 0.41 \\
\hline $\mathrm{CP} \mathrm{mic} / \mathrm{TDN}^{2}$ & 120 & 117 & 113 & 114 & 9.01 & 0.64 & 0.81 & 0.88 \\
\hline
\end{tabular}

${ }^{1}$ mic $\mathrm{N}=$ microbial $\mathrm{N} ; \mathrm{RDOM}=$ rumen-degraded organic matter; $\mathrm{RDCHO}=$ rumen-degraded carbohydrate.

${ }^{2} \mathrm{~g} / \mathrm{kg}$.

${ }^{3}$ Probability of a significant linear, quadratic, or cubic effect of the levels of sorghum silage in diet.

\section{DISCUSSION}

There was a high variation in the quality of the silages, likely due to intrinsic differences of material ensiled. The low quality of grass silage probably is consequence of its low water soluble carbohydrate (WSC) content, high buffering capacity, and high moisture at the moment of ensilage, resulting in poor quality silage with high $\mathrm{pH}$ and $\mathrm{NH}_{3}-\mathrm{N}$ /Total $\mathrm{N}$ values (Table 1). Additionally, the grass silage had a dark color and characteristic smell of badly-preserved silage which suggest poor fermentation. On the other hand, the sorghum silage had adequate $\mathrm{pH}$ and $\mathrm{NH}_{3}-\mathrm{N} /$ Total $\mathrm{N}$ values. According to Muck and Pitt (1993), $\mathrm{pH}$ and $\mathrm{NH}_{3}-\mathrm{N} /$ Total $\mathrm{N}$ values 
above 5.0 and $10 \%$, respectively, suggest poor fermentation of forage ensiled. Therefore, sorghum silage had a better quality than grass silage.

Furthermore, the grass silage presented higher numeric values of cell wall contents and lesser values of DM, EE, and NFC than the sorghum silage. Consequently, the diets with more sorghum silage had more energy. Thus, as expected, the nutritional value of diets was improved with sorghum silage increase (Table 2).

Overall, the intake of the majority of nutrients linearly increased $(\mathrm{P}<0.05)$ when grass silage was replaced by sorghum silage (Table 3 ). This behavior was expected due to the poor fermentation characteristics of grass silage (low DM content, high $\mathrm{pH}$ and $\mathrm{NH}_{3}-\mathrm{N}$, dark color, and strong smell of butyric acid) and its high content of structural carbohydrate (NDF, ADF, lignin, and $\mathrm{iADF}$ ). These fermentation characteristics had a negative effect on DMI of the grass silage because of its probable low palatability. On the other hand, its high structural carbohydrate contents resulted in grass silage diet with lesser energy than those with sole and greater levels of sorghum silage. Church (1993) reported that feeds with great contents of fiber are less digestible, and, frequently limits the DMI due to the filling of the rumen. However, according to Van Soest (1994), the DMI does not reach that limit with low quality silages, and, probably other aspects affect their DMI.

The intake of NDF, $\mathrm{kg} / \mathrm{d}$, was not affected by the levels of sorghum silage, and had a mean value of $2.26 \mathrm{~kg} / \mathrm{d}$. In contrast, the NDF intake, \% of $\mathrm{BW}$, had a linear and quadratic behavior. However, the quadratic function explained more the variation than linear function $\left(\mathrm{R}^{2}=0.93\right.$ and 0.49 , respectively). Thus, the maximum intake of NDF was $1.01 \%$ BW with $66.1 \%$ of sorghum silage in the diet forage.

Souza et al. (2006) fed steers with different proportions of Tifton- 85 haylage and sorghum silage and observed increase on intake of EE and NFC when sorghum silage was added to the diets. On the other hand, Feijó et al. (2001) evaluated the effect of grass (Panicum maximum) and sorghum silages on the performance of Nellore cows and observed greater DMI by cows fed sorghum silage than grass silage (2.8 and $2.2 \%$ of BW, respectively). These authors concluded that grass silage had poor fermentation and lower quality than sorghum silage. O'Mara et al. (1998) evaluated the effect of replacing grass silage by corn silage on DMI and milk production in dairy cows and observed that DMI improved as corn silage increased. Phipps et al. (1995, 2000) also observed a significant increase in voluntary DMI of forage when maize silage was incorporated into grass silage-based diets.

The incorporation of the sorghum silage in the diet improved $(\mathrm{P}<0.05)$ the apparent total digestibility of DM, OM, and NDF, likely due to its lower content of structural carbohydrate than in the grass silage. The apparent total digestibility of CP, EE, and NFC were not affected by treatments and averaged 66.7, 79.1, 47.8 , and $87.6 \%$, respectively. Cavalcante et al. (2004) observed no differences among digestibility of DM, OM, CP, and EE of steers fed diets with increasing levels of corn silage replacing Tifton-85 hay. However, the authors reported a quadratic effect of NDF digestibility with maximum digestibility of $65.2 \%$ of diets with $31 \%$ of corn silage. On the other hand, Chizzotti et al. (2005) evaluated the effect of replacing grass silage by sorghum silage on the performance and the digestibility of nutrients in Nellore steers and observed increases of DM, $\mathrm{OM}, \mathrm{CP}$, and NDF total digestibility.

Overall, only the ruminal digestibilities of DM, $\mathrm{OM}$, and EE were affected $(P<0.05)$ by sorghum silage in the diet. The negative coefficients of EE for ruminal digestibility indicate that occurred synthesis of lipids in the rumen and the linear effect probably resulted from the greater intake of EE by steers fed diets with more or sole sorghum silage than those fed grass-based diet (Table 5). The high values of ruminal digestibility of CP suggested an imbalance over time between available energy and $\mathrm{N}$ in all diets, maybe due to the high level of forage $(60 \%)$, resulting in a greater availability of $\mathrm{N}$ than available energy and a positive apparent $\mathrm{CP}$ ruminal digestibility due to the ruminal absorption of the $\mathrm{N}$ excess.

There were no effects of the levels of sorghum silage on the apparent intestinal digestibility of $\mathrm{CP}, \mathrm{EE}, \mathrm{NDF}$, and NFC, which averaged 45.1, 
$81.3,13.8$, and $25.5 \%$, respectively. In contrast, the intestinal digestibility of DM and OM linearly decreased $(\mathrm{P}<0.05)$ as grass silage was replaced by sorghum silage.

The ruminal $\mathrm{pH}$ values were only affected by time sampling (Fig, 1) with minimum of 5.87 at $5.21 \mathrm{~h}$ after feeding. This value is below of range from 6.2 to 7.0 , for adequate fiber digestion suggested by Hoover (1986). However, according to this author, the decrease in fiber digestion probably will occur in a $\mathrm{pH}$ range from 5.5 to 5.0. Cavalcante et al. (2004) observed minimum ruminal $\mathrm{pH}$ of 5.98 at $6.82 \mathrm{~h}$ after feeding when replaced Tifton- 85 hay by corn silage. On the other hand, Souza et al. (2003) evaluated the replacement of Tifton 85 haylage by sorghum silage and reported no effect of treatments and sampling time after feeding on ruminal $\mathrm{pH}$ values, which averaged 6.21.

Ruminal NH3-N concentrations were also affected $(\mathrm{P}<0.05)$ only by time sampling with maximum of $13.63 \mathrm{mg} / \mathrm{dL}$ at $2.94 \mathrm{~h}$ after feeding (Fig. 2). These results suggested that ruminal $\mathrm{NH}_{3}-\mathrm{N}$ concentrations were sufficient for microbial protein production because of minimum value cited by NRC (Nutrient ..., 1989 ) is $5 \mathrm{mg} / \mathrm{dL}$. Hoover (1986) suggested that maximization of microbial production and fiber digestion occur in a range from 3.3 to $8.0 \mathrm{mg} / \mathrm{dL}$ of ruminal NH3-N. Souza et al. (2003) observed maximum ruminal NH3-N concentration of $13.14 \mathrm{mg} / \mathrm{dL}$ at $2.9 \mathrm{~h}$ after feeding in steers fed diets with different proportions of Tifton-85 haylage and sorghum silage.

The means of passage rate, estimated by NRC (Nutrient ..., 2001) equations, were 4.1, 4.5, 5, and $4.8 \% / \mathrm{h}$ to diets with $0,33,67$, and $100 \%$ of sorghum silage, respectively. The maximum estimated passage rate was $4.95 \% / \mathrm{h}$ to diets with $79.6 \%$ of sorghum silage. These data are in accordance with data of DMI, \%BW, which also had a quadratic behavior with maximum intake of $2.5 \% \mathrm{BW}$ to diets with $79.6 \%$ of sorghum silage in dietary forage.

It was observed an increasing in microbial nitrogen production probably due to an improvement on the intake of nutrients as grass silage was replaced by sorghum silage. According to Clark at al. (1992), as DMI increases, passage rate also increases, and consequently, the passage rate of microbes to intestine enhances, decreasing the recycling of energy and $\mathrm{N}$ in the rumen. Thus, there is a reduction in the requirements of maintenance of the microorganisms and, consequently, more nutrients still available in the rumen to microbial protein production. Additionally, RDOM and RDCHO increased with the levels of sorghum silage and likely provided ruminal microbes with more fermentable substrates in the rumen.

However, even though the microbial synthesis was increased, the microbial efficiency was not affected $(\mathrm{P}>0.05)$ by treatments (Table 6). The microbial efficiency had a mean value of $116 \mathrm{~g}$ $\mathrm{CP}$ microbial $/ \mathrm{kg}$ TDN, which is below of the $130 \mathrm{~g}$ of CP microbial/kg TDN suggested by the NRC (Nutrient ..., 2001). When expressed as $g$ microbial N/kg RDOM and as g microbial N/kg RDCHO, the mean values were 30.3 and 32.2 , respectively. The ARC (The nutrient..., 1984) suggests microbial efficiency of $32 \mathrm{~g}$ microbial $\mathrm{N} / \mathrm{kg}$ RDOM, which is nearly identical to the value found in the study.

\section{CONCLUSIONS}

The combination of $67 \%$ of sorghum silage and $33 \%$ of grass silage was the good alternative for forage supplementation of Holstein $\mathrm{x}$ Nellore crossbred steers. The intake and digestibility of nutrients of this combination were close to those obtained when only sorghum silage was fed, without affecting ruminal $\mathrm{pH}$, ruminal $\mathrm{NH} 3-\mathrm{N}$, and microbial efficiency. Therefore, the choice of silages or the combination of both will depend on cost and facility of make them.

\section{REFERENCES}

BOLSEN, K.K.; LIN, C.; BRENT, B.E. et al. Effect of silage additives on the microbial succession and fermentation process of alfalfa and corn silages. J. Dairy Sci., v.75, p.30663083, 1992.

CATCHPOOLE, V.R.; HENZELL, E.F. Silage and silage making from tropical herbage species. Herb. Abstr., v.41, p.213-221, 1971.

CAVALCANTE, A.C.R.; PEREIRA, O.G.; VALADARES FILHO, S.C. et al. Dietas contendo silagem de milho (Zea maiz l.) e feno de capim-tifton 85 (Cynodon spp.) em diferentes proporções para bovinos. Rev. Bras. Zootec., v.33, p.2394-2402, 2004. 
CHIZZOTTI, F.H.M.; PEREIRA, O.G.; VALADARES FILHO, S.C. et al. Consumo, digestibilidade total e desempenho de novilhos nelore recebendo dietas contendo diferentes proporções de silagens de Brachiaria brizantha cv. marandu e de sorgo. Rev. Bras. Zootec., v.34, p.2427-2436, 2005.

CHURCH, D.C. The ruminant animal: Digestive physiology and nutrition. Prospect Heights, IL: Waveland Press, 1993. 564p.

CLARK, J.H.; KLUMEYER, T.H.; CAMERON, M.R. Microbial protein synthesis and flows of nitrogen fractions to the duodenum of dairy cows. J. Dairy Sci., v.75, p.2304-2323, 1992.

FEIJÓ, G.L.D.; THIAGO, L.R.L.S.; SILVA, J.M. Uso de silagens e concentrados contendo milho ou casca de soja para engorda de vacas em confinamento.In: REUNIÃO ANUAL DA SOCIEDADE BRASILEIRA DE ZOOTECNIA, 38., 2001, Piracicaba. Anais...Piracicaba: SBZ, 2001. CDROM.

FERREIRA, J.J.; ZUNINGA, M.C.P.; VIANA, M.C.M. Silage of mixture of elephant grass (Pennisetum purpureum, schum) and corn versus mixture of silages of elephant grass and corn on the performance of dairy heifers. Rev. Bras. Zootec., v.24, p.1027-1037, 1995.

HALL, M.B. Calculation of non-structural carbohydrate content of feeds that contain nonprotein nitrogen. Gainesville, FL: University of Florida, 2000. p.A-25. (Bulletin, 339).

HOOVER, W.H. Chemical factors involved on ruminal fiber digestion. J. Dairy Sci., v.69, p.2755-2766, 1986.

IMURA, Y.; NAMIHIRA, T.; KAWAMOTO, $Y$. Fermentation quality of phasey bean and guinea grass silages. In: GOMIDE, J.A.; MATTOS, W.R.S..; SILVA, S.C. (Ed.). INTERNATIONAL GRASSLANDS CONGRESS, 19., 2001, São Paulo. Proceedings..., Piracicaba: Japan Grassland Farming Forage Seed Association, 2001. p.784785.

KUEHL, R.O. Design of experiments: statistical principles of research design and analysis. 2.ed. New York: Duxbury, 2000. 700p.

LEÃO, M.I.; COELHO DA SILVA, J.F. Técnicas de fistulação de abomaso em bezerros. In: REUNIÃO ANUAL DA SOCIEDADE
BRASILEIRA DE ZOOTECNIA, 17., 1980. Fortaleza. Anais... Fortaleza: SBZ, 1980. p.37. (Resumo).

MUCK, R.E.; PITT, R.E. Ensiling and its effect on crop quality silage. In: SILAGE PRODUCTION FROM SEED TO ANIMAL. PROCEEDINGS, 67., 1993, New York, NY. New York: Natural Resource, Agriculture, and Engineering Service, 1993. p.57-66.

NUTRIENT requirements of dairy cattle. 6.ed. Washington, DC: National Academic Press, 1989.

NUTRIENT requirements of dairy cattle. 7.ed. Washington, DC: National Academy Press, 2001. p.381.

OFFICIAL methods of analysis, 15.ed. Arlington, VA: AOAC, 1990.

O'MARA, F.P.; FITZGERALD, J.J.; MURPHY, J.J. et al. The effect on milk production of replacing grass silage with maize silage in the diet of dairy cows. Livest. Prod. Sci., v.55, p.7987, 1998.

PHIPPS, R.H.; SUTTON, J.D.; BEEVER D.E. et al. The effect of crop maturity on the nutritional value of maize silage for lactating dairy cows. 3 . Food intake and milk production. Anim. Sci., v.71, p.401-409, 2000.

PHIPPS, R.H.; SUTTON, J.D.; JONES, B.A. Forage mixtures for dairy cows: the effect on dry matter intake and milk production of incorporating either fermented or urea-treated whole-crop wheat, brewers' grains fodder beet or maize silage into diets based on grass silage. Anim. Sci., v.61, p.491-496, 1995.

RENNÓ, L.N. Consumo, digestibilidade total e parcial, produção microbiana, parâmetros ruminais e excreções de uréia e creatinina em novilhos alimentados com dietas contendo quatro níveis de uréia ou dois de proteina. 2003. 252f. Tese (Doutorado) - Universidade Federal de Viçosa, Viçosa, MG.

ROBERTSON, J.B.; VAN SOEST, P.J. The detergent system of analysis and its application to human foods. In: JAMES, W.P.T.; THEANDER, O. The analysis of dietary fiber in food. New York: Marcel Dekker, 1981. p.123158. 
SNIFFEN, C.J.; O'CONNOR, J.D.; VAN SOEST, P.J. et al. A net carbohydrate and protein system for evaluating cattle diets: II. Carbohydrate and protein availability. J. Anim. Sci., v.70, p.3562-3577, 1992.

SOUZA, V.G.; PEREIRA, O.G.; VALADARES FILHO, S.C. et al. Consumo, digestibilidade e parâmetros ruminais de bovinos de corte recebendo dietas contendo silagem de sorgo e pré-secado de capim-tifton 85. In: REUNIÃO ANUAL DA SOCIEDADE BRASILEIRA DE ZOOTECNIA, 40., 2003, Santa Maria, RS. Anais... Santa Maria: SBZ, 2003. CDROM.

SOUZA, V.G.; PEREIRA, O.G.; VALADARES FILHO, S.C. et al. Efeito da substituição de présecado de capim-tifton 85 por silagem de sorgo no consumo e na digestibilidade dos nutrientes e no desempenho de bovinos de corte. Rev. Bras. Zootec., v.35, p.2479-2486, 2006.

THE NUTRIENT requirements of ruminant livestock. Supplement n.1: Report of the protein group of the ARC working party. Farnham Royal: CAB, 1984. 45p.

USHIDA, K.; LASSALAS, B.; JOUANY, J.P. Determination of assay parameters for RNA analysis in bacterial and duodenal samples by spectrophotometry: Influence of sample treatment and preservation. Reprod. Nutr. Dev., v.25, p.1037-1046, 1985.
VAN SOEST, P.J. Nutritional ecology of the ruminant. 2.ed. London: Constock, 1994. 476p.

VAN SOEST, P.J.; ROBERTSON, J.B.; LEWIS, B.A. Methods for dietary fiber, and nonstarch polysaccharides in relation to animal nutrition. $J$. Dairy Sci., v.74, p.3583-3597, 1991.

WILLIAMS, C.H.; DAVID, D.J.; IISMAA, O. The determination of chromic oxide in fecal samples by atomic absorption spectrophotometry. J. Agric. Sci., v.59, p.381385, 1962.

WILKINSON, J.M.; NEWMAN, G.; ALLEN, D.M. Maize: Producing and feeding maize silage. Lincoln, UK: Chalcombe Pub., 1998. 102 p.

ZAGO, C.P. Silagem de sorgo. In: SIMPÓSIO SOBRE NUTRIÇÃO DE BOVINOS: ALIMENTAÇÃO SUPLEMENTAR, 7., 1999, Piracicaba. Anais... Piracicaba: FEALQ, 1999. p.47-68. 